UNDERSTANDING PHASE DIAGRAMS 
Other Engineering titles from Macmillan Education

John: An Introduction to Engineering Materials

Radford and Richardson: Production Engineering Technology, 2nd edition

Radford and Richardson: The Management of Production, 3rd edition

Redford, Rimmer and Titherington: Mechanical Technology, 2nd edition

Redford: Mechanical Engineering Design, 2nd edition. Revised in SI units 


\section{Understanding \\ PHASE DIAGRAMS}

V. B. JOHN M.sc, C..ев, M.M.M., A..M.

Senior Lecturer in Engineering

The Polytechnic of Central London

Macmillan Education 
(c) V. B. John 1974

Reprint of the original edition 1974

All rights reserved. No part of this publication may be reproduced or transmitted, in any form or by any means, without permission

First published 1974 by THE MACMILLAN PRESS LTD London and Basingstoke Associated companies in New York Dublin Melbourne Johannesburg and Madras

SBN 333149890

Typeset in Great Britain at

PREFACE LIMITED

Salisbury, Wilts., 


\section{Contents}

Preface

1 PHASE SYSTEMS 1

Introduction - Phases - Components - The phase rule Thermodynamic considerations - Metastable states

2 ONE-COMPONENT SYSTEMS

Water - Degrees of freedom or variance - The phase diagram - The critical point - Sublimation - Allotropy - Sulphur Monotropy - Iron

\section{BINARY LIQUID SYSTEMS}

Representation of a binary system - Liquid mixtures with complete solubility - Boiling point curves showing maximum or minimum - Interpretation of phase diagrams - Liquid mixtures showing no miscibility - Liquid mixtures with partial miscibility

4 LIQUID-SOLID SYSTEMS

Condensed systems - Total solid insolubility - Interpretation - Solid solubility - Phase diagram for total solid solubility Partial solid solubility - Peritectic diagram - Compound formation - Solidification of partially miscible and immiscible liquid mixtures - Effects of phase diagram type on the properties of alloys - Effect of allotropy on a phase diagram - Aqueous solutions - Ternary diagrams

5 REAL SYSTEMS

Solid solutions - Eutectics - Precipitation hardening - The iron-carbon system - Systems with intermediate phases Ceramic systems - Polymer systems 
6 EXPERIMENTAL DETERMINATION OF PHASE DIAGRAMS

Introduction - Freezing-point determination - Solvus lines and eutectoids - Dilatometry - Microscopy - Use of X-rays - Other methods

REVISION QUESTIONS

INDEX

92 


\section{Preface}

My colleagues and I have observed that many students, in particular students of engineering, seem to find great difficulty in understanding the principles of phase diagrams. In consequence, I thought that there could be many students who would appreciate the existence of a monograph on this subject. Normally the student of engineering is only informed about the $p-t$ diagram for water and $t-c$ phase diagrams for binary alloy systems. I believe that phase diagrams will be more readily appreciated if the subject is given some unity and to this end I have chosen to include vapour pressure curves and $t-c$ diagrams for liquid mixtures in this small work. While the book is intended primarily for those following courses in engineering or metallurgy, it is to be hoped that students in other disciplines might find the volume of some interest and value.

Chapter 5, which deals with some specific alloy systems, seeks only to indicate the relationships which exist between phase diagrams, structure and properties, including the existence of metastable phases, for a few major systems. It is not intended that this chapter be a comprehensive review as there are numerous full definitive works available which deal with the properties of alloys.

I would like to thank my colleague, Clive Beesley, for his assistance with manuscript checking, and I am greatly indebted to my wife for her patience and understanding during the gestation period of this work and for converting an often almost illegible manuscript into type.

V. B. John 